\title{
The use of mouthwashes by 17-year-old youth
}

\author{
Stosowanie płynów do jamy ustnej przez młodzież 17-letnią
}

\author{
Jolanta Irena Szymańska, ${ }^{1, A, C-F}$, Ewa Olejnik ${ }^{1, B-D \oplus}$ \\ ${ }^{1}$ Department of Integrated Paediatric Dentistry, Chair of Integrated Dentistry, Medical University of Lublin, Poland \\ A - Research concept and design, B - Collection and/or assembly of data, C - Data analysis and interpretation, \\ $D$ - Writing the article, E - Critical revision of the article, F - Final approval of article
}

Szymańska Jl, Olejnik E. The use of mouthwashes by 17-year-old youth. Med Og Nauk Zdr. 2020; 26(3): 275-279. 10.26444/monz/127359

\begin{abstract}
Introduction and objectives. The principal methods of preventing the formation of dental plaque is its mechanical removal by brushing with a toothbrush and toothpaste and using mouthwashes. The aim of the study was evaluation of the frequency of use and kind of mouthwashes used, factors affecting the choice of particular mouthwash, and knowledge concerning those products by 17-year-old youths.

Materials and method. A survey study comprised 270 randomly selected high school students. The obtained results were statistically analyzed.

Results. The study proved that mouthwashes are used by slightly more than $1 / 3$ of the youths, whereas only $14 \%$ of them use them frequently enough. The most popular mouthwashes in this age group are those of recognizable international brands, which widely advertise their products. Commercials are the main source of knowledge about mouthwashes which are purchased mainly in drugstores. The choice of mouthwash is determined by its price and taste, while the aim of using the products is better oral freshness. The vast majority of the youths did not have any knowledge concerning mouthwashes, were unfamiliar with their content, and did not pay attention to the inclusion of active ingredients when buying.

Conclusions. Low awareness concerning the methods and principles of oral hygiene was proved. There is a need for broader promotion of the use of mouthwashes in everyday hygiene, as well as for a more in-depth knowledge about the right choice of such products depending on the prophylactictherapeutic recommendations.
\end{abstract}

\section{Key words}

oral hygiene, young people, mouthwashes, survey and questionnaire

\section{Streszczenie}

Cel pracy. Podstawową metodą zapobiegania tworzenia się płytki nazębnej jest jej mechaniczne usuwanie poprzez szczotkowanie szczoteczką i pastą do zębów oraz stosowanie płynów do płukania jamy ustnej. Celem pracy była ocena częstości i rodzaju stosowanych płynów do jamy ustnej, czynników mających wpływ na wybór płukanki do jamy ustnej i wiedzy na ich temat wśród 17-letniej młodzieży.

Materiał i metody. Badaniem ankietowym objęto losowo wybranych 270 uczniów szkół średnich. Uzyskane wyniki poddano analizie statystycznej.

Wyniki. Przeprowadzone badanie wykazało, że płukanki do pielęgnacji jamy ustnej stosuje nieco ponad 1/3 młodzieży, przy czym odpowiednio często używa ich jedynie 14\% osób. W tej grupie wiekowej najbardziej popularnymi płynami do płukania jamy ustnej są produkty znanych firm międzynarodowych, które szeroko reklamują swoje produkty. Podstawowym źródłem wiedzy na temat płukanek do jamy ustnej są reklamy, a głównym miejscem ich zakupu - drogerie. Na wybór płukanki do jamy ustnej ma wpływ jej cena i smak, a celem jej stosowania jest uzyskanie większej świeżości jamy ustnej. Zdecydowana większość młodzieży nie posiada wiedzy na temat płukanek do jamy ustnej - nie zna ich składu i podczas zakupu nie zwraca uwagi na zawartość w nich składników czynnych.

Wnioski. Potwierdzono niski poziom wiedzy na temat metod i zasad dbałości o higienę jamy ustnej. Istnieje potrzeba propagowania bardziej powszechnego stosowania płynów do płukania jamy ustnej w jej codziennej higienie i pogłębiania wiedzy na temat odpowiedniego ich doboru w zależności od wskazań profilaktyczno-leczniczych.

\section{Słowa kluczowe}

młodzież, higiena jamy ustnej, badanie ankietowe, płyny do płukania jamy ustnej

\section{INTRODUCTION}

The principal method of maintaining oral hygiene is brushing the teeth with a toothbrush and toothpaste. Efficacy of hygienic procedures also largely depends on the

Address for correspondence: Jolanta Irena Szymańska, Department of Integrated Paediatric Dentistry, Chair of Integrated Dentistry, Medical University, Lublin, Poland

E-mail: szymanska.lublin@gmail.com

Received: 07.08.2020; accepted: 08.09.2020; first published: 16.09.2020 use of additional methods, including mouthwashes, dental floss, toothpicks and irrigators. Mouthwashes should be treated as a complementation of basic mechanic cleaning methods, and not as their substitution. Apart from their use in oral hygiene, mouthwashes are applicable in various pathological conditions, for instance, in gum diseases [1]. Before a particular mouthwash is used, the following factors should be taken into consideration: person's ability to maintain good oral hygiene (e.g. toothbrushing, dental floss), condition of the periodontium, teeth and oral mucosa, as well 
as a mouthwash mode of action and its potential side-effects [2]. The content of mouthwashes should be adjusted to the patient's individual needs, and the choice ought to be made by a dentist who takes preventive and therapeutic care of the patient. Regular washing mouth after brushing teeth needs to be performed once or twice a day.

\section{OBJECTIVE}

The aim of the study was evaluation of the frequency of the use of mouthwashes by 17-year-old youths, and the factors affecting their choice of a particular mouthwash.

\section{MATERIALS AND METHOD}

A group of 270 students, including 130 girls and 140 boys, aged 17 years \pm 3 months, were randomly select from four high schools in Lublin, and asked the following question: 'Do you use mouthwashes in order to maintain good oral hygiene?' From this group, 167 respondents (86 girls and 81 boys) replied that they do not use any mouthwashes. These students were excluded from the survey.

Values of the analyzed parameters were presented in the form of figures and percentages. In order to study interdependency between the examined characteristics, Pearson's chi-squared test was used. The significance level was indicated as $\mathrm{p}<0.05$. Statistical analyses wer performed using the programme SPSS $14 \mathrm{PL}$.

\section{RESULTS}

Among the total number of participants, 103 used mouthwas (38.15\%). This group included 44 girls (43\%) and 59 boys (57\%). No statistically significant differences were found between the genders when it came to number of persons from particular groups using mouthwashes.

The distribution of answers given to the survey questions among the 17-year-olds who used mouth rinses is presented in Table 1.

The study proved that mouthwashes are used by slightly more than $1 / 3$ of the youths, whereas only $14 \%$ use them sufficiently frequently. The most popular mouthwashes in this age group were those of recognizable international brands, which widely advertise their products. Commercials were the main source of knowledge about mouthwashes, which were purchased mainly from drugstores. The choice of mouthwash was determined by its price and taste, while the aim of using the product was better oral freshness. The vast majority of the youths did not have any knowledge concerning mouthwashes, were not familiar with their content, and did not pay an attention to the inclusion of active ingredients when buying.

\section{DISSCUSSION}

Among young people, the use mouthwashes is not common. As own survey shows, only $38.15 \%$ of the 17 -year-old youths use mouthwashes in oral care, and no statistically significant difference was found between the genders. Silva et al. [3] in their own studies stated that approximately $75 \%$ of the youths aged 10-19 years evaluated their oral cavity condition as very good, emphasizing that the reason for that is the use of various methods of maintaining good oral health, including mouthwashes.

In the own studies, it was found out that only slightly more than $1 / 3$ of those who use mouthwashes, use them once-twice a day, which is the proper way of acting from the dental prophylaxis point of view. Whereas a similarly large group use them a few times a month. Therefore, $2 / 3$ of all the respondents use mouthwashes too seldom. Although, as an expected health-oriented behaviour contributing to improvement in oral hygiene, $67.44 \%$ among 258 participants - primary, junior high and high school student - considered using mouthwashes [4].

Girls use mouthwashes more frequently than boys, which may be connected with the greater awareness of girls about the care and maintenance of good oral hygiene. Similar results were obtained by Granville-Garcia et al. [5], who also stated that girls more often use additional methods of maintaining good oral hygiene, compared to boys. Likewise, more frequent occurrence of better health behaviours concerning oral cavity in adult young women was found by Tada and Handa [6], as well as in another study, which was proved that women more often than men use mouthwashes in Scotland [1].

In their studies, Calderon and Mallory [7] alleged that approximately $2 / 3$ of the American youth aged $12-18$ years use mouthwashes, while almost half of the respondents use them once a day. The results obtained in the own studies and those of the American researchers prove the existing meaningful difference between the awareness of the young Americans and young Poles concerning the maintaining of a good oral condition and positive health behaviours.

According to own studies, the mouthwashes most often used are those of recognizable brands, such as Colgate-Palmolive, Johnson \& Johnson, or Procter \& Gamble, and commercials are the source of knowledge about them. Adverisements are the most frequent source of knowledge concerning mouthwashes for the Polish youth and largely refers to boys. The least numerous group was given information concerning mouth rinses by a dentist. The greatest number of girls and boys found out about mouthwashes from commercials. However, the number of boys was not significantly bigger than the number of girls who learned about the use of the product from other sources. The group including boys, who were informed about a mouthwash by a dentist, was less numerous than the group of girls. It seems that girls are more willing to look for other sources of reliable information concerning the given product, and not influenced only by adverts.

Commercials are one of the major sources regarding the choice of a product. Everybody feels more secure buying something he/she has already heard about, than in the case of a totally new and unknown product. The commercials appearing in the media have considerable impact on making consumers' decisions by young people [8]. Awareness concerning the fact that a product is advertised gives a consumer confidence that this product is good, trusted and recommendable. Lapierre et al. [9] stated that children above 7 years of age and youths are a group especially prone to the influence of commercials. Many companies design adverts for their products in such a way that they are also attractive for the youngest greneration. Certain techniques are used 
Table 1. Distribution of answers given to the survey questions

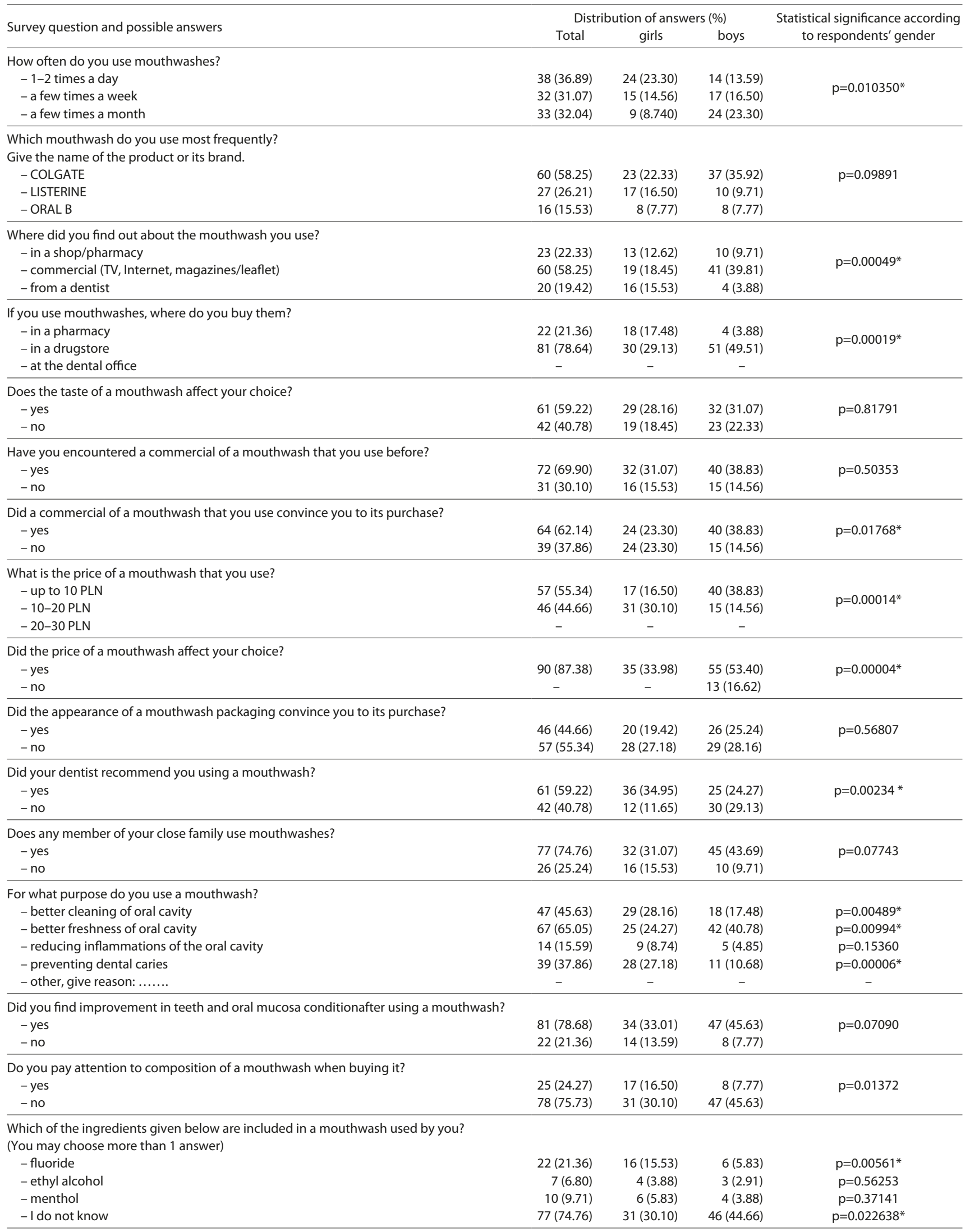


for attracting the attention of young people, eye-catching images, colours, as well as sound effects. The presence of peers in the advertisements of products is also meaningful for the recipients, who are more eager to buy the presented product.

According to own studies, the places where mouthwashes are purchased mainly include drugstores, followed by pharmacies. In this regard, differences between the genders concern a greater number of girls buying the products in pharmacies, compared to boys. Purchasing mouthwashes in pharmacies may indicate the need for obtaining professional pharmaceutical advice, depending on the demand. Pharmacists are helpful in giving comprehensive information regarding a given therapeutic product [10].

The price of a mouthwash was significant for the majority of the respondents using mouthwashes. It considerably affected the choice of the product, especially in the case of boys. None of them answered that the price was insignificant when selecting a mouthwash. The studies by Albari and Safitri showed that the products of a recognizable brand at an attractive price were more often bought by consumers [11]. In turn, an insignificant factor influencing the purchase of a mouthwash was the appearance of the packaging. For the majority of participants using mouthwashes, irrespective of this was important when buying a product.

The use of mouthwashes by girls was connected with obeying the recommendations of a dentist. The conducted survey showed that a considerable difference between boys and girls concerned the fact whether a mouthwash was purchased after the recommendation of a dentist to use this product. The vast majority of girls responded that a dentist advised them to use a mouthwash in everyday oral hygiene. The major part of boys claimed that their dentist did not make any such recommend to use this product. The influence of persons from the close environment is equally important when making a decision, and showing positive patterns is particularly vital. Garbin et al. [12] evaluated what influence a group of parents had on the oral health condition of their children. Among the study group, approximately $1 / 5$ of participants and their children used mouthwashes. It was found out that the use of additional methods of maintaining good oral hygiene by parents, including dental flosses, mouthwashes, toothpicks and irrigators, positively affected maintaining good oral hygiene by their children.

Better freshness of the oral cavity was the most frequent reason of using mouthwashes especially for boys; this answer was given by about half of those using mouthwashes. For $1 / 3$, it was important that the product prevents caries. The majority of this group included girls, whereas for the boys, this reason was not particularly important. Reducing inflammation of the oral mucosa and periodontium was the cause of purchase for the least numerous group of youths, which is undoubtedly connected with their age and lower needs in this matter. Both girls and boys noticed improvement in the condition of their teeth and oral mucosa after the use of a mouthwash, and positively assessed their oral health. It can be assumed that the expectations concerning mouthwashes among the tudy participants were met.

In own studies, the vast majority of respondents did not have any knowledge concerning the ingredients of the mouthwash they used. Very few of them knew that the product they used contains fluoride, menthol and alcohol. The number of girls who were aware of this was bigger than the number of boys. Researchers in India conducted a survey among the youths aged 11-15 years in which it was found that less than $2 \%$ of respondents had knowledge concerning the fluoride content of a toothpaste they use [13]. Therefore, it seems that level of knowledge of the young people on ingredients in products and the presence of anti-caries substances in oral hygiene products is insufficient. Girls, however, are more aware when buying mouthwashes and are substantially more affected by recommendations from dental offices where they search for guidance. Mouthwashe commercials, similar to their prices, are not as important for the girls as they are for boys. It should be emphasized that there is a need for a greater contribution of dentists to youth education during visits to a dental office [14].

The main aim of health education is to provide appropriate information in order to increase health awareness, develop necessary skills, and repeat and multiply the transmitted content [15]. The audit conducted in the years $2014-2016$ by the Supreme Audit Office, the aim of which was evaluation of the accessibility of children and youths up to the age of 18 years of age in the Lublin Province to free dental services, showed that this province provided one of the best services in the country services, especially through the functioning of 164 school dental offices. The procedures financed within the National Health Service, apart from medical examination with oral hygiene instruction, did not provide education for children and their parents in the scope of health promotion [16]. Favourable conditions for shaping positive oral health behaviours and habits, which could serve as a health guarantee in the future, were not used. The consequence, among others, is an insufficient level of knowledge concerning the methods and principles of taking care of oral hygiene, which was proved in the own studies.

\section{CONCLUSION}

Low awareness concerning the methods and principles of oral hygiene was proved in the group of 17-year-old youths. There is therefore a need for broader promotion of the use of mouthwashes in everyday hygiene, as well as for a more indepth knowledge of the right choice of the product, depending of the prophylactic-therapeutic recommendations.

\section{REFERENCES}

1. Macfarlane TV, Kawecki MK, Cunningham C, et al. Mouthwash use in general population: Results from adult dental health survey in Grampian, Scotland. J Oral Maxillofac Res. 2010; 1(4): e2. doi: 10.5037/ jomr.2010.1402

2. Farah CS, McIntosh L, McCullough MJ. Mouthwashes. Aust Prescr. 2009; 32: 162-164. doi: 10.18773/austprescr.2009.080

3. Silva EKP, Santos PR, Chequer TPR, et al. Oral health of quilombola and non-quilombola rural adolescents: a study of hygiene habits and associated factors. CienSaudeColet 2018; 23(9): 2963-2978. doi: 10.1590/1413-81232018239.02532018

4. Król M, Grobelny M. Wiedza dzieci i młodzieży z województwa lubelskiego na temat zastosowania przyborów higienicznych w profilaktyce próchnicy zębów. Med Og Nauk Zdr Med. 2014; 20(3): 335-340. doi: 10.5604/20834543.1124668

5. Granville-Garcia AF, Fernandes LV, Farias TSS, et al. Adolescents' knowledge of oral health: a population based study. Rev Odonto Cient. 2010; 25(4): 361-366.

6. Tada A, Hanada N. Sexual differences in oral health behaviour and factors associated with oral health behaviour in Japanese young adults. Public Health. 2004; 118(2): 104-109. doi: 10.1016/j. puhe.2003.05.007 
7. Calderon SJ, Mallory C. Look at my pearly white teeth: Exploring adolescents' oral health behaviour. Pub. Health Nurs. 2019; 36: 62-69. https://doi.org/10.1111/phn.12569

8. Pabalkar V, Balgaonkar V. The effects of advertising on youth. Int J Manag. 2014; 5(6): 63-70.

9. Lapierre MA, Fleming-Milici F. The effect of advertising on children and adolescents. Pediatrics. 2017; 140(s2): 152-158. doi: 10.1542/ peds.2016-1758V

10. Waszyk-Nowaczyk M, Simon M, Szukalska B. Opieka farmaceutyczna płaszczyzną współpracy lekarza i farmaceuty. Now Lek. 2013; 82(3): 262-265.

11. Albari, SafitriI.The influence of product price on consumers purchasing decisions. Review of Intergrative Business and Economics Research. 2018; 7(2): 328-337.

12. Garbin CAS, Soares GB, Dócusse FRM, et al. Oral health education in school: parents' attitudes and prevalance of caries in children. Rev Odontol UNESP. 2015; 44(5): 185-291. https://doi.org/10.1590/1807-2577.0097
13. Mishra A, Pandey RK, Chopra H, et al. Oral health awarness in schoolgoing children and its significance to parent's education level. J Indian Soc Pedod Prev Dent. 2018; 36(2): 120-124. doi: 10.4103/JISPPD. JISPPD_1172_17

14. Tylewicz A, Woynarowska-Sołdan M. Wykorzystanie techniki „Narysuj i napisz” w praktyce lekarza dentysty sprawującego opiekę nad dziećmi. Nowa Stom. 2013; 1: 3-11.

15. Hawkins RJ, Zanetti DL, Main PA, et al. Oral hygiene knowledge of high-risk Grade One children: an evaluation of two methods of dental health education. Community Dent Oral Epidemiol. 2000, 28: 336-343. https://doi.org/10.1034/j.1600-0528.2000.028005336.x

16. Najwyższa Izba Kontroli. Delegatura w Lublinie. Profilaktyka stomatologiczna dzieci i młodzieży w województwie lubelskim. LLU.430.001.2017 Nr ewid. 64/2017/P/16/077/LLU file://C:/Users/ oem/Downloads/llu-p_16_077_201703241232481490358768-01.pdf (dostęp: 2020.07.01) 